\title{
Prioritering hører hjemme i politikken
}

\author{
Hvilke diagnostikk- og behandlingsmetoder som skal tilbys av den offentlige helsetjenesten, følger av lov- \\ givningen om innbyggernes rettigheter. Beslutninger om helsetjenestens omfang tilhører det politiske nivået. \\ Klinikere skal ikke pådyttes slike avgjørelser.
}

\section{Marit Halvorsen}

marit.halvorsen@jus.uio.no

I et solidarisk finansiert helsevesen må det være samsvar mellom byrder som pålegges (skatter, avgifter) og goder som ytes til individene (f.eks. helsetjenester), for at systemet skal ha politisk legitimitet. Vi kan gå ut fra at det er alminnelig enighet om at det må være en grense for hvor store ressurser som brukes på helsevesenet. I et land med store offentlige bevilgninger, ofte til formål som av mange betraktes som mindre viktige enn den offentlige helsetjenesten, er det likevel vanskelig å begrunne hvorfor en bestemt medisinsk behandling ikke skal ytes, eller hvorfor noen pasientgrupper skal utelates.

Størrelsen på helsetjenestens budsjett må bestemmes ut fra hvilke tjenester befolkningen tilbys og hvilken kvalitet tjenestene skal ha. Helselovgivningens standard er at helsehjelp skal være «faglig forsvarlig» og «omsorgsfull» (1). I Norge i dag betyr det at det vanligvis må stilles høye krav til helsehjelpens kvalitet og omfang. Disse kravene legger føringer for utgiftsnivået. Politikere kan ikke fritt fastsette helsebudsjettene; de er bundet av loven. Men loven gir selvfølgelig et spillerom, og det er fritt frem for lovgiver å presisere eller endre omfanget av tjenestetilbudet. Ressursbegrensning er en del av politikkens dagsorden.

\section{Første- og}

\section{annenordensbeslutninger}

I 1978 introduserte de amerikanske juristene Guido Calabresi og Philip Bobbitt skillet mellom «first order determinations» og «second order determinations» og la dermed til rette for en nyansert debatt om prioritering av samfunnsressurser (2). Beslutninger om ressursbruk, som definerer rammene for et visst samfunnsgode eller samfunnsonde, betegnes som «førsteordensbeslutninger», mens beslutninger om hvordan den fastsatte mengde goder eller onder skal fordeles, er «annenordensbeslutninger». Førsteordensbeslutningene tilhører de politiske fora, mens annenordensbeslut- ningene tas der den konkrete fordelingen finner sted, i helsesektorens tilfelle i klinisk praksis. I diskusjonen om ressurser og fordeling av helsetjenester er det viktig å holde disse nivåene atskilt.

Typiske førsteordensbeslutninger kan være «alle som får ødelagt sine knær gjennom skader eller degenerative sykdommer, skal få kneprotese» eller «levertransplantasjon skal utføres i Norge». Annenordensbeslutningene blir da knyttet til svar på spørsmål som «Er denne pasientens kne ødelagt? Vil pasienten ha nytte av knepro-

\section{«l et solidarisk finan-} siert helsevesen må det være samsvar mellom

\section{byrder som pålegges og goder som ytes til individene»}

tese?» eller «Er denne pasientens leversvikt av en slik art at ny lever er indisert? Og vil denne pasienten kunne tåle påkjenningen ved en transplantasjon?» Annenordensbeslutninger kan også innebære å velge hvem av flere pasienter som av medisinske grunner bør få behandling først.

Eventuelt kan førsteordensbeslutningen være «pasienter eldre enn 80 år skal ikke få hofteproteser». Her utløser førsteordensbeslutningen det enkle spørsmålet om pasientens alder. En annen førsteordensbeslutning kan være «vi skal behandle hundre pasienter med en bestemt sykdom per år», noe som medfører en lang rekke kompliserte, kanskje uløselige fordelingsspørsmål: Skal de 100 velges ut etter hvor syke de er, eller etter hvor mye nytte de vil ha av behandlingen? Skal de unge prioriteres fremfor de eldre, småbarnsforeldre fremfor andre, skal halvparten være menn og halvparten kvinner, skal det tas hensyn til geografisk fordeling? Et siste eksempel er «sykehus X skal ha budsjett på y kroner», et eksempel som kompliserer den kliniske hverdagen ytterligere.

Annenordensbeslutningstakerne får prioriteringer i fanget som de ikke er skikket til å ta: Når man skal velge hvem som skal få behandling, kan man ikke bare følge medisinskfaglig logikk. Det er tale om fordeling av offentlige ressurser, og de avveininger som må foretas, har en politisk dimensjon. Det innebærer at det må gis overordnede føringer for de kliniske beslutningene. Dette har også vært forsøkt, sågar i to omganger, gjennom to innstillinger om prioritering: Lønning-utvalget I og Lønningutvalget II (3) og etterfølgende arbeider. Mengden offentlige dokumenter om prioritering er imponerende. Men effekten er ikke imponerende: For pasientene ser det ut som om klinikere stadig foretar fordelingspolitiske beslutninger som bare vanskelig kan tvinges inn i faglige begrunnelser.

Hvis førsteordensbeslutningene ble tatt ordentlig og åpent, ville både de som tar annenordensbeslutningene og pasientene som blir gjenstand for disse beslutningene, vite hva de har å holde seg til: Alle som trenger det, får kneprotese. Der levertransplantasjon er indisert, blir pasienten satt på venteliste. 100 pasienter med sykdommen er heldige, og de som ikke er heldige, må skylde på førsteordensbeslutningstakerne. Pasienter eldre enn 80 år vet at det ikke er aktuelt å få ny hofte. På denne måten blir systemet forutsigbart, og det er mulig å føre meningsfylte diskusjoner om prioritering.

\section{Retten til helsetjenester}

Førsteordensbeslutningene som gjelder norsk helsetjeneste er lovfestet og vidtgående. Pasienter har rett til øyeblikkelig hjelp uten begrensninger og for øvrig til nødvendig helsehjelp som kan ha nytte, forutsatt at kostnadene står i rimelig forhold til effekten (4). Per i dag (juni 2013) foreligger et forslag om å forenkle lovteksten slik at formulering om forventet nytte og kostnadseffektivitet tas ut og at rettigheten formuleres bare som «rett til nødvendig helsehjelp» (5). Utover dette er det sagt lite som begrenser retten til behandling. Folketrygdloven har bestemmelser som 


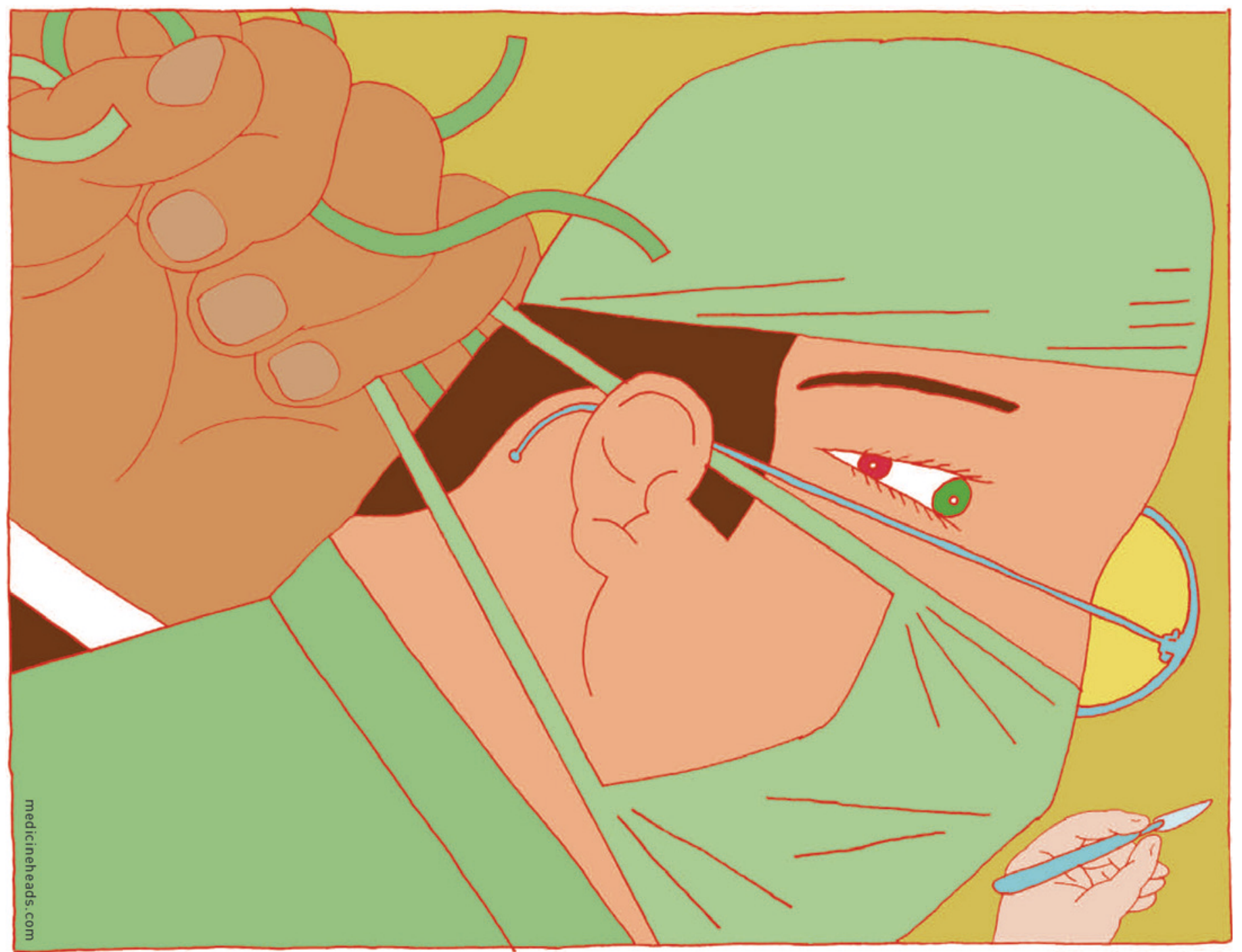

Illustrasjon ๑ Trond Nordahl/medicineheads

viser at «nødvendig helsehjelp» ikke omfatter behandling som først og fremst er kosmetisk begrunnet og at tannlegehjelp bare ytes etter nærmere bestemte regler (6). Utover disse to begrensningene har det tradisjonelt ikke vært noen lovbestemt begrensning på helsetjenestenes omfang. Vurderingen av hvem som skal behandles, hvilken behandling som skal tilbys og i hvilket omfang, er overlatt til fagfolkene.

Den tidligere legeloven påla leger å ikke sløse med pengene. Samme påbud gis i dag $\mathrm{i}$ helsepersonelloven $\S 6$. I grunnen lå størrelsen på helsebudsjettet gjemt i lovtekstene: Pasienten skulle få slik forsvarlig og omsorgsfull hjelp som legen mente var nødvendig, på syketrygdens regning, men uten sløseri. Rett til helsehjelp på disse betingelsene ble innført med sykeforsikringsloven av 1909 (7). Nyere lovgivning, det vil særlig si pasientrettighetsloven fra 1999, gjorde ingen egentlig endring på dette, men innførte noen presiseringer av vilkårene for å kunne kreve hjelp, nemlig «forventet nytte» og «kostnader i rimelig forhold til tiltakets effekt» (4).

\section{Heldekkende helsetjeneste}

Det finnes en forskrift, den såkalte prioriteringsforskriften, som knytter «nødvendig» til redusert livskvalitet, svekkede vitale funksjoner eller nedsatt funksjonsnivå, og «nytte» til forbedret livskvalitet, økt livslengde eller til å unngå forverring eller tap av behandlingsmulighet (8). Det er med andre ord tale om medisinskfaglige vurderinger. Det fremgår av forskriftens tekst at det ikke skal veldig mye til før helsehjelpen anses som nødvendig og/eller nyttig. Den bruker uttrykk som «ikke ubetydelig nedsatt livskvalitet». «Forventet nytte» knyttes opp mot dokumentasjon av effekt, men det kreves ikke mer enn at pasienten kan oppleve forbedret livskvalitet eller livslengde av «en viss varighet», eller at tilstanden «kan» forverres eller at behandlingsmulighet «kan» forspilles. Det er ikke noe som tyder på at den foreslåtte endringen i lovteksten vil få noen særlig betydning for hva som reguleres av forskriften. Det blir ikke noen utvidet adgang til å kreve helsehjelp som ikke kan virke eller som er ekstremt kostbar i forhold til nytten.

Kriteriet om at de forventede kostnadene skal stå i rimelig forhold til tiltakets effekt, er ikke godt forklart. En formulering fra Helsedirektoratets prioriteringsveileder for hjertemedisinske sykdommer gjenfinnes mange steder: «Vilkåret om kostnadseffektivitet krever at det skal være et rimelig forhold mellom kostnadene ved helsehjelpen og helsehjelpens forventede nytteeffekt. Her er det forholdet mellom kostnadene på den ene siden og nytten av helsehjelpen på den andre siden, som skal vurderes. Kostnadene isolert sett skal ikke 
være avgjørende» (9). Dette er nokså intetsigende. Antakelig henviser forskriftsteksten til en slags magefølelse. Magefølelsen ble satt på prøve i vinterens debatt om bruk av ipilimumab (mot føflekkreft med spredning) og abirateron (mot prostatakreft). «Folk» godtok ikke helsedirektørens sparebegrunnelser.

En oppsummering av lover og forskrifter må bli: Det rettslige utgangspunktet er at norsk helsetjeneste er noermest heldekkende. Med andre ord: Førsteordensbeslutningene gir borgerne utstrakte rettigheter

\section{«Over tid kan mis- forholdet mellom berettiget forventning og virkelighetens ytelser gi opphav til mange onder»}

som først og fremst skal begrenses av medisinsk begrunnede årsaker, knyttet til at behandling ikke vil bety stort verken fra eller til for pasienten. Dette burde tilsi at annenordensbeslutningene kan konsentreres om utøvelse av medisinskfaglig skjønn.

\section{Rettigheter må følges av ressurser}

Lovens kapasitetsbeslutninger er ikke mye verdt hvis de ikke følges av tilstrekkelige ressurser i form av penger, personale, utstyr og lokaler. Og her starter problemene. Helsetjenesten skal budsjettstyres og den skal gå med overskudd - eller i hvert fall ikke med underskudd. Selve ideen om overog underskudd i helsetjenesten, som om den skulle være en produksjonsbedrift, er egentlig absurd, men la nå det ligge. Vi kan være enige om at det er fornuftig å ha kontroll med ressursbruken i helsetjenesten, på samme måte som $\mathrm{i}$ andre samfunnssektorer. Men budsjettstyring uten tydelig overordnet prioritering skaper et problem: Bor- gerne har all grunn til å tro at de har krav på behandling som for dem fremstår som nødvendig og med realistisk sjanse til å virke og som ikke åpenbart sprenger fornuftige ressursrammer. Det kommer derfor som en ubehagelig overraskelse når de oppdager at «øyeblikkelig hjelp» kan bety «når det blir tid», eller at det er lang ventetid på enkle diagnostiske undersøkelser, eller at de må gå sykmeldt $i$ en lang periode før de kan få en kurant operasjon. Over tid kan misforholdet mellom berettiget forventning og virkelighetens ytelser gi opphav til mange onder.

Når førsteordensbeslutningene er vidtrekkende, men følges av for små ressurser, blir kapasitetsbeslutninger skjøvet ned til det kliniske nivået, der de ikke hører hjemme. I stedet for å følge medisinsk rasjonelle retningslinjer for prioritering av de gitte ressurser, blir helsepersonell potensielle lovbrytere fordi de må nekte pasienter helsetjenester de etter lovteksten har krav på. Dessuten kan helsepersonell komme i klemme mellom den lovpålagte plikten til å gi forsvarlig helsehjelp og det administrative pålegget om å holde budsjettet. (OBS: Forsvarlighetsplikten veier tyngst her - man kan miste autorisasjonen hvis man handler uforsvarlig. Budsjettpålegget må vike!) Helsepersonell blir stående som vrange og onde når pasienter blir underdiagnostisert, underbehandlet, overbehandlet, feilbehandlet, får behandlingen utsatt eller blir sendt hjem for tidlig. Helsevesenet får skylden når tjenestene ikke er gode nok. Bare sjelden rettes søkelyset mot de beslutninger som skaper forventning fra borgernes side: De uklare signalene om prioritering og de bevisst for trange ressursrammene.

Antakelig brukes det for lite penger på helsetjenesten til at løftene i lovgivningen kan oppfylles (10). Hvis førsteordensbeslutningstakerne - politikerne - mener at det ikke skal brukes mer penger på helse, må de ta seg sammen og bestemme hva som ikke lenger skal utføres innenfor den offentlige helsetjenesten. Hvis de mener at lovgivningen om helsetjenestens omfang er riktig under de rådende politiske og økonomiske forhold, må de bevilge tilstrekkelige midler.

Helsetjenesteaksjonen (11) har som ett av sine krav at politikerne tar ansvar for å defi- nere rammebetingelser for helsetjenesten. Førsteordensbeslutningene må være tydelige, slik at helsepersonell slipper å gjøre politikernes jobb. Det er loven, og ikke budsjettet, som skal bestemme omfanget av helsetjenesten.

\section{Marit Halvorsen (f. 1957)}

er dr.jur. og professor ved Institutt for offentlig rett, Universitetet i Oslo. Doktorgradsarbeidet omhandlet helserettslige emner.

Forfatter har fylt ut ICMJE-skjemaet og oppgir ingen interessekonflikter.

\section{Litteratur}

1. LOV 1999-07-02 nr. 64: Lov om helsepersonell m.v. (helsepersonelloven). www.lovdata.no/all/ hl-19990702-064.html (29.7.2013).

2. Calabresi G, Bobbit P. Tragic choices. New York, NY: W.W: Norton \& Company, 1978.

3. NOU 1987: 23, NOU 1997: 18 Prioritering på ny. www.regjeringen.no/nb/dep/hod/dok/nouer/1997/ nou-1997-18.html?id=140956 (29.7.2013).

4. LOV 1999-07-02 nr. 63: Lov om pasient- og brukerrettigheter (pasient- og brukerrettighetsloven). Kapittel 2: §§ 2-1a, 2-1b. www.lovdata.no/all/ hl-19990702-063.html\#map002 (29.7.2013).

5. Prop. 118 L (2012-2013): Endringer i pasient- og brukerrettighetsloven mv. (rett til nødvendig helsehjelp og pasientrettighetsdirektivet m.m.). $\S 2-1 b, 2$. ledd. www.regjeringen.no/nb/dep/hod/ dok/regpubl/prop/2012-2013/prop-118-l20122013.html?id=722646 (29.7.2013).

6. LOV 1997-02-28 nr. 19: Lov om folketrygd lfolketrygdloven). § 5-1, 2. ledd, § 5-4. www. lovdata.no/ all/hl-19970228-019.html (29.7.2013).

7. Halvorsen M. Rett til behandling i sykehus. Oslo: Universitetsforlaget, 1997.

8. FOR-2000-12-01-1208: Forskrift om prioritering av helsetjenester, rett til nødvendig helsehjelp fra spesialisthelsetjenesten, rett til behandling i utlandet og om klagenemnd (prioriteringsforskriften). www.lovdata.no/for/sf/ho/ ho-20001201-1208. html (29.7.2013).

9. Helsedirektoratet. Prioriteringsveileder - hjertemedisinske sykdommer. Oslo: Helsedirektoratet, 2009: 15. www.helsedirektoratet.no/publikasjoner/ prioriteringsveileder-hjertemedisinskesykdommer/Sider/default.aspx (29.7.2013)

10. Jensen B. Feil diagnose gir feil behandling. Overlegen 2012; 2: 22-3

11. Helsetjenesteaksjonen. www.helsetjenesteaksjonen.no (29.7.2013).

Mottatt 14.5. 2013 og godkjent 18.6. 2013. Medisinsk redaktør Hanne Støre Valeur.

Publisert først på nett. 